\title{
PENENTUAN DEBIT ANDALAN DENGAN METODA FJ MOCK DI DAERAH ALIRAN SUNGAI CISADANE
}

\author{
Teddy W Sudinda \\ Pusat Teknologi Lingkungan, BPPT, Kawasan Puspiptek, Tangerang Selatan, 15314, Indonesia \\ Email: teddy.sudinda@gmail.com
}

\begin{abstract}
ABSTRAK
Prinsip metode Model FJ Mock menyatakan hujan yang jatuh pada daerah tangkapan air, sebagian akan hilang akibat evapotranspirasi, sebagian akan langsung menjadi direct runoff dan sebagian lagi akan masuk ke dalam tanah atau terjadi infiltrasi. Infiltrasi ini semula akan menjenuhkan permukaan tanah, kemudian terjadi perkolasi ke air tanah dan akan keluar sebagai base flow Hal ini terdapat keseimbangan antara air hujan yang jatuh dengan evapotranspirasi, direct runoff dan infiltrasi, dimana infiltrasi ini kemudian berupa soil moisture dan ground water discharge. Aliran dalam sungai adalah jumlah aliran yang langsung di permukaan tanah dan base flow. Curah hujan rata-rata bulanan di daerah pengaliran sungai dihitung berdasarkan data pengukuran curah hujan dan evapotranspirasi yang sebenarnya dari data meteorologi dengan menggunakan metode Penman dan karakteristik vegetasi. Perbedaan antara curah hujan dan evapotranspirasi mengakibatkan limpasan air hujan langsung (direct runoff), aliran dasar/air tanah dan limpasan air hujan lebat (storm runoff). Dengan metoda Model FJ Mock, dapat digunakan untuk menganalisa debit andalan untuk Daerah Aliran Sungai Cisadane.
\end{abstract}

Kata kunci: Base Flow, Direct Runoff, Storm Runoff

\section{DETERMINATION OF MAINSTAY DISCHARGE WITH FJ MOCK METHOD IN CISADANE RIVER BASIN}

\author{
Teddy W Sudinda \\ Center for Environmental Technology, BPPT, Puspiptek Area, South Tangerang, 15314, Indonesia \\ Email: teddy.sudinda@gmail.com
}

\begin{abstract}
The principle of the FJ Mock Model method states that rain falls in the water catchment area, some will be lost due to evapotranspiration, some will directly become direct runoff and some will enter the soil or infiltrate. This infiltration will initially saturate the soil surface, then percolation into the ground water and will come out as the base flow. There is a balance between falling rainwater and evapotranspiration, direct runoff and infiltration, wherein the infiltration is in the form of soil moisture and ground water discharge. Flow in the river is the amount of flow directly at the ground and base flow. The average monthly rainfall in the river drainage area is calculated based on rainfall measurement data and actual evapotranspiration from meteorological data using the Penman method and vegetation characteristics. The difference between rainfall and evapotranspiration results in direct runoff, groundwater / groundwater and storm runoff. With the FJ Mock Model method, it can be used to analyze the mainstay discharge for the Cisadane River Basin.
\end{abstract}

Keyword: Base Flow, Direct Runoff, Storm Runoff

\section{LATAR BELAKANG}

Sumber air DAS Cisadane berasal dari Taman Nasional Gunung Gede Pangrango (TNGGP) dan Taman Nasional Halimun Salak (TNGHS). Aliran sungai Cisadane mengalir sejauh $1.047 \mathrm{Km}$ dari kawasan hulu hingga hilir. Aliran sungai ini banyak dimanfaatkan oleh masyarakat yang bermukim di sekitar bantaran untuk memenuhi kebutuhan hidup sehari-hari dengan pola pemanfaatan yang beragam. Berdasarkan topografinya, bagian hulu DAS Cisadane merupakan daerah berbukit dengan ketinggian mencapai $3.000 \mathrm{~m}$ dpl dan kemiringan lereng mencapai $40 \%$. Sedangkan bagian hilir sampai bagian tengah merupakan daerah datar hingga bergelombang. DAS Cisadane bagian hulu yang meliputi Kabupaten Bogor dan sebagian Kota Bogor didominasi oleh penggunaan lahan berupa hutan, ladang, perkebunan, pemukiman dan lahan kosong. Sedangkan di bagian tengah dan hilir, penggunaan lahan didominasi oleh pemukiman, ladang dan lahan kosong yang dapat dilihat pada Gambar 1. 


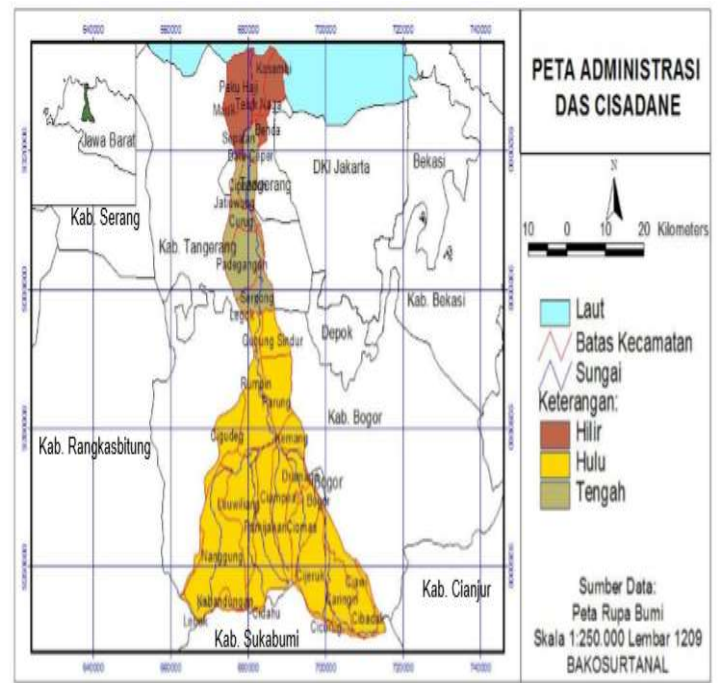

Gambar 1. Wilayah administrasi DAS Cisadane Sumber: BBWS Ciliwung-Cisadane

DAS Cisadane dibatasi oleh sub DAS Cimanceuri di sebelah barat dan DAS Cisadane di sebelah timur. Sungai Cisadane berhulu di Gunung Salak dan Gunung Pangrango, Kabupaten Bogor (Propinsi Jawa Barat) dan mengalir ke arah Utara melalui Kotamadya dan Kabupaten Tangerang (Propinsi Banten) dan bermuara di Laut Jawa.

Menurut toposekuens-nya dibagi ke dalam tiga bagian, yaitu: hulu, tengah dan hilir, masingmasing dengan stasiun pengamatan arus sungai di Batu Belah Bogor, Dramaga Bogor, dan Pasar Baru Tangerang.

\subsection{Topografi}

Kondisi topografi dan tingkat kecuraman lereng di DAS Cisadane terdiri dalam variasi kemiringan dari daerah hulu sampai daerah hilir. Di daerah hulu memiliki variasi lereng yang curam, tetapi semakin ke daerah hilir tingkat kemiringan lereng menjadi lebih landai bahkan datar. Kemiringan lahan atau kelas lereng di DAS Cisadane dibagi enam kelas kemiringan, dimana kelas yang mendominasi adalah kelas kemiringan lahan datar $(0-3 \%)$. Kelas datar ini menyebar di bagian hilir dan tengah DAS Cisadane. Sedangkan pada bagian hulu lebih banyak terdapat lahan yang berombak dan bergelombang. Pada daerah pegunungan seperti di kecamatan Ciawi dan Cijeruk kemiringan lahan berupa lahan yang berbukit sampai terjal (Gambar 2).

Luas kelas kemiringan lahan datar $(0-3 \%)$ adalah $1018,76 \mathrm{~km}^{2}$ dengan persentase $68,52 \%$. Sedangkan kelas kemiringan dengan luasan paling kecil adalah kelas kemiringan lahan berbukit curam/terjal dengan luas $54,46 \mathrm{Ha}$ dengan persentase $0,03 \%$ lihat Tabel 1 .

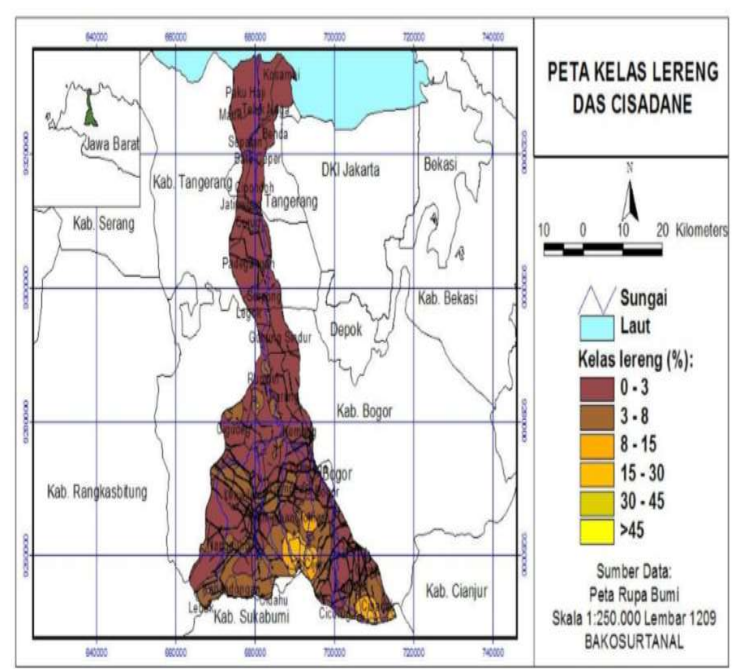

Gambar 2. Peta Kelas Lereng DAS Cisadane Sumber : BBWS Ciliwung-Cisadane

Tabel 1. Kemiringan lereng wilayah kajian

\begin{tabular}{|l|l|l|l|}
\hline No & $\begin{array}{c}\text { Kelas Kemiringan } \\
\text { Lereng }\end{array}$ & Persentase & $\begin{array}{c}\text { Luas } \\
\mathbf{( k m}^{\mathbf{2}}\end{array}$ \\
\hline 1 & $0-3$ (Datar) & $68,52 \%$ & $1.018,76$ \\
\hline 2 & $3-8$ (Berombak) & $23,66 \%$ & 351,76 \\
\hline 3 & $8-15$ (Bergelombang) & $5,02 \%$ & 74,68 \\
\hline 4 & $15-30$ (Berbukit kecil) & $2,44 \%$ & 36,23 \\
\hline 5 & $30-45$ (Berbukit) & $0,03 \%$ & 4,89 \\
\hline 6 & $>45$ (Terjal) & $0,03 \%$ & 0,52 \\
\hline \multicolumn{2}{|l|}{ Total } & $100,0 \%$ & $1.486,84$ \\
\hline
\end{tabular}

\subsection{Tekstur Tanah}

Dari Peta Tekstur Tanah (Gambar 3) dapat dilihat bahwa kelas yang paling luas untuk tekstur tanah adalah kelas sangat halus. Sebagian besar kelas tekstur tanah sangat halus ini terdapat pada bagian tengah dan hulu DAS Cisadane. Bagian hulu umumnya mempunyai kelas tekstur tanah sedang.

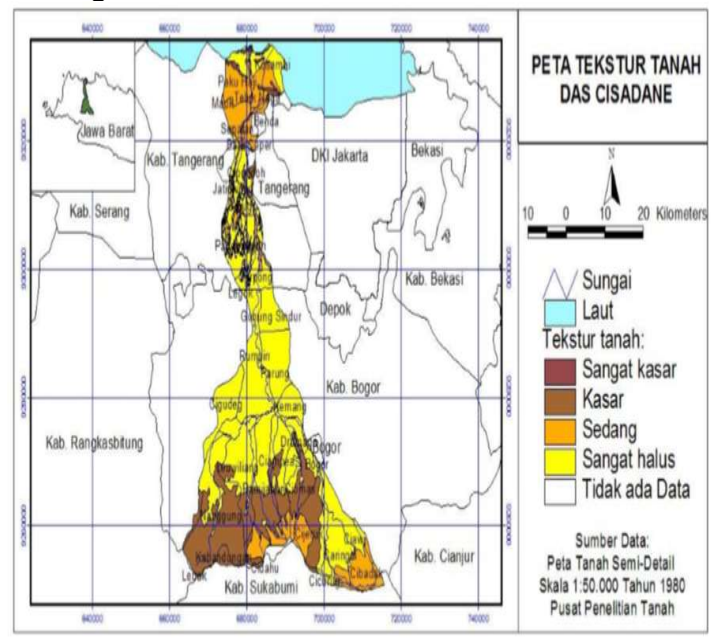

Gambar 3. Peta Tekstur Tanah DAS Cisadane Sumber: BBWS Ciliwung-Cisadane 
Tekstur tanah DAS Cisadane umumnya adalah tekstur tanah sangat halus, dimana kelas tekstur tanah sangat halus ini mempunyai luasan $850,37 \mathrm{~km}^{2}$ atau $57,19 \%$ dari seluruh luas DAS Cisadane. Kelas tekstur tanah yang paling kecil luasannya adalah kelas sangat kasar dengan luas $9,08 \mathrm{~km}^{2}$ dengan persentase 0,61\% lihat Tabel 2 . Karena sifat kelas tekstur tanah sangat halus ini yang menahan air luapan sungai meresap ke dalam tanah, memberikan pengaruh bahwa banyak daerah di DAS Cisadane susah menyerap air sehingga timbul penggenangan air dan memperbesar kemungkinan terjadi banjir.

Tabel 2. Tekstur tanah DAS Cisadane

\begin{tabular}{|l|l|l|l|}
\hline No & Tekstur Tanah & $\begin{array}{c}\text { Persentase } \\
\text { (\%) }\end{array}$ & Luas (km2) \\
\hline 1 & Sangat Kasar & 0,61 & 9,08 \\
\hline 2 & Kasar & 22,37 & 332,61 \\
\hline 3 & Sedang & 18,45 & 274,36 \\
\hline 4 & Sangat Halus & 57,19 & 850,37 \\
\hline \multicolumn{2}{|l}{ Total } & 100,0 & $1.486,82$ \\
\hline
\end{tabular}

Sumber: Puslittanak, 2007

\subsection{Tata Guna Lahan}

DAS Cisadane mempunyai bentuk topografi yang bervariasi dari hulu hingga hilir. Wilayah hulu merupakan pegunungan dengan ketinggian $300 \mathrm{mdpl}-3000 \mathrm{mdpl}$, wilayah tengah merupakan dataran dengan ketinggian $100 \mathrm{mdpl}$ - 300 mdpl, dan wilayah hilir merupakan dataran rendah dengan ketinggian 0 mdpl - 100 mdpl. Luas kelas lereng yang terdapat di DAS Cisadane disajikan dalam Tabel 3. Diketahui bahwa dominasi kelas lereng yang berada di DAS Cisadane adalah pada kelas lereng datar dengan persentase $67,51 \%$ dari total luas DAS. Kelas lereng datar pada umumnya berada pada DAS Cidasane bagian tengah dan hilir. Jika kondisi fisik khususnya perubahan penggunaan lahan berubah, maka akan mengakibatkan perubahan yang nyata terhadap karakteristik aliran sungai.

Kondisi tata guna lahan berdasarkan Tutupan Lahan Hasil Analisa yang disajikan dalam Tabel 3 diketahui bahwa terjadi perubahan peningkatan kawasan permukiman, industri dan permukiman dari luas WS. Dengan demikian kebutuhan air baku untuk permukiman perkotaan dan industri akan meningkat, sedangkan kebutuhan air untuk irigasi kemungkinan akan menurun.

Tabel 3. Kondisi tata guna lahan di WS Cisadane

\begin{tabular}{|l|c|c|}
\hline \multicolumn{1}{|c|}{ Keterangan } & $\begin{array}{c}\text { Persentase } \\
\mathbf{( \% )}\end{array}$ & $\begin{array}{c}\text { Luas } \\
\mathbf{( k m}^{2} \mathbf{)}\end{array}$ \\
\hline Air Tawar & $1,0 \%$ & 50,48 \\
\hline Belukar/semak & $5,1 \%$ & 269,11 \\
\hline Empang & $1,5 \%$ & 80,51 \\
\hline Hutan & $5,1 \%$ & 267,79 \\
\hline
\end{tabular}

\begin{tabular}{|l|c|c|}
\hline \multicolumn{1}{|c|}{ Keterangan } & $\begin{array}{c}\text { Persentase } \\
\mathbf{( \% )}\end{array}$ & $\begin{array}{c}\text { Luas } \\
\mathbf{( k m}^{\mathbf{2}} \mathbf{)}\end{array}$ \\
\hline Hutan Rawa & $0,0 \%$ & 1,35 \\
\hline Kebun/Perkebunan & $12,1 \%$ & 639,25 \\
\hline Pasir Darat & $0,0 \%$ & 2,39 \\
\hline Pasir Pantai & $0,0 \%$ & 0,01 \\
\hline Pemukiman & $27,7 \%$ & 1459,75 \\
\hline Penggaraman & $0,0 \%$ & 0,34 \\
\hline Rawa & $0,2 \%$ & 11,23 \\
\hline Rumput/Tanah & $7,2 \%$ & 380,01 \\
\hline Kosong & $24,1 \%$ & 1269,62 \\
\hline Sawah Irigasi & $5,5 \%$ & 289,97 \\
\hline Sawah Tadah Hujan & $0,1 \%$ & 6,13 \\
\hline Tanah Berbatu & $10,3 \%$ & 541,59 \\
\hline Tegalan/ladang & $100,0 \%$ & $5.269,52$ \\
\hline \multicolumn{2}{|c|}{} \\
\hline
\end{tabular}

Sumber : Studi Pola Pengelolaan SDA WS Ciliwung

- Cisadane, Tahun 2012

\subsection{Hidrologi}

Sungai Cisadane dengan daerah tangkapan seluas 151.808 ha, merupakan salah satu sungai utama di Propinsi Banten dan Jawa Barat. Fluktuasi aliran Sungai Cisadane sangat bergantung pada curah hujan di daerah tangkapannya (catchment area). Aliran yang tinggi terjadi saat musim hujan dan menurun saat musim kemarau. Debit normal Sungai Cisadane sebesar $70 \mathrm{~m} 3 /$ detik. Berdasarkan pemantauan yang dilakukan di stasiun pengamat Serpong antara tahun 1971 hingga 1997, aliran terendah yang pernah terjadi sebesar $2,93 \mathrm{~m}^{3} /$ detik di tahun 1991 dan tertinggi 973,35 m3/detik tahun 1997. Berdasarkan catatan bulanan antara tahun 1981 dan 1997, aliran minimum terjadi antara bulan Juli dan September dengan rata-rata aliran di bawah $25 \mathrm{~m}^{3} /$ detik. Pembagian Sub DAS Cisadane dapat dilihat pada Gambar 4.

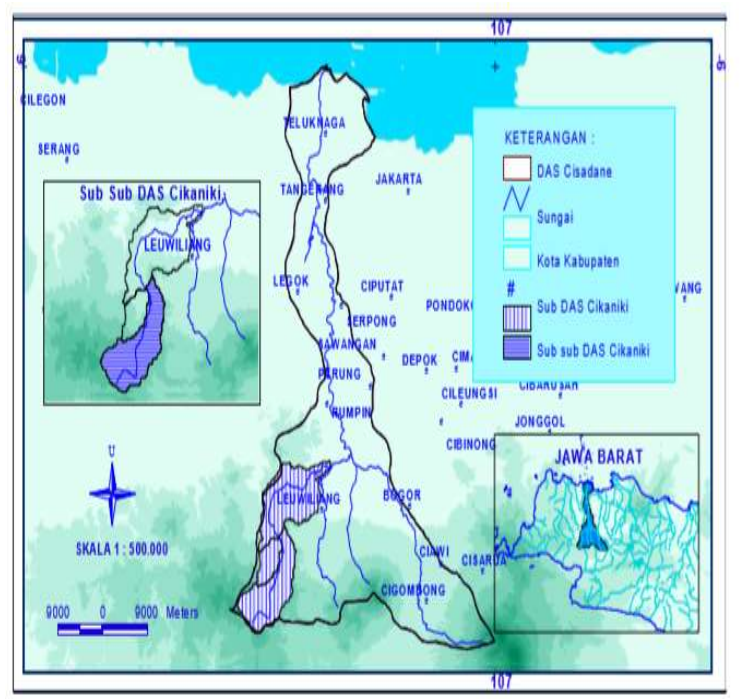

Gambar 4. Peta Pembagian Sub-DAS Cisadane Sumber: BBWS Ciliwung-Cisadane 
Luas Pengaruh wilayah Sub DAS Cisadane terdiri dari 25 Sub DAS dengan luas total 1.343,77 $\mathrm{Km} 2$. Untuk lebih jelasnya dapat dilihat pada Tabel 4.

Tabel 4. Luas pengaruh wilayah Sub DAS Cisadane

\begin{tabular}{|l|l|l|}
\hline No & \multicolumn{1}{|c|}{ Sub DAS } & \multicolumn{1}{|c|}{ Luas $\mathbf{( K m}^{\mathbf{}} \mathbf{)}$} \\
\hline 1 & Cisadane Hulu & 46,09 \\
\hline 2 & Cinagara & 41,79 \\
\hline 3 & Cisalopa & 30,36 \\
\hline 4 & Citamiang & 56,43 \\
\hline 5 & Cigombong & 69,20 \\
\hline 6 & Cimanggis & 56,97 \\
\hline 7 & Cikalong & 61,95 \\
\hline 8 & Cigintung & 58,05 \\
\hline 9 & Cigembrong & 184,49 \\
\hline 10 & Cimande & 48,91 \\
\hline 11 & Cikereteg & 44,48 \\
\hline 12 & Cipaku & 35,20 \\
\hline 13 & Ciapus & 15,31 \\
\hline 14 & Cihideung & 49,86 \\
\hline 15 & Cinangneung & 56,84 \\
\hline 16 & Ciampea & 70,01 \\
\hline 17 & Ciaruten & 23,91 \\
\hline 18 & Cianten & 41,79 \\
\hline 19 & Cikaniki & 117,31 \\
\hline 20 & Cipinang & 14,91 \\
\hline 21 & Cihowe & 62,35 \\
\hline 22 & Jelentreng & 10,88 \\
\hline 23 & Cisauk & 77,69 \\
\hline 24 & Cicayur & 44,47 \\
\hline 25 & Cisabik & 25,67 \\
\hline & TOTAL & $1.343,77$ \\
\hline & & \\
\hline
\end{tabular}

DAS Cisadane mempunyai curah hujan rata-rata antara 2.200 - >3.600 mm, Bagian utara DAS Cisadane yang mendekati kawasan pantai memiliki tingkat curah hujan yang lebih kecil dibanding bagian hulu yang ada di bagian selatan. Hal ini berkaitan dengan topografi dan bentuk lahan. Pada DAS Cisaadane terdapat beberapa pos hujan yang dipilih untuk mewakili bagian DAS Cisadane yaitu hulu, tengah dan hilir, yang dapat dilihat pada Tabel 5.

Tabel 5. Pos Stasiun Hujan DAS Cisadane

\begin{tabular}{|l|l|l|l|}
\hline No & $\begin{array}{c}\text { Segmen } \\
\text { DAS }\end{array}$ & $\begin{array}{c}\text { Pos } \\
\text { Hujan }\end{array}$ & Kabupaten/Kota \\
\hline 1 & \multirow{4}{*}{ Hulu } & Leuwiliang & $\begin{array}{l}\text { Kabupaten } \\
\text { Bogor }\end{array}$ \\
\cline { 4 - 4 } 2 & & Ciomas & $\begin{array}{l}\text { Kabupaten } \\
\text { Bogor }\end{array}$ \\
\hline 3 & \multirow{4}{*}{ Tengah } & Dramaga & $\begin{array}{l}\text { Kabupaten } \\
\text { Bogor }\end{array}$ \\
\cline { 4 - 4 } & & Ciampea & $\begin{array}{l}\text { Kabupaten } \\
\text { Bogor }\end{array}$ \\
\hline 4 & \multirow{2}{*}{ Hilir } & Neglasari & $\begin{array}{l}\text { Kabupaten } \\
\text { Tangerang }\end{array}$ \\
\hline & & Serpong & Kota Tang-Sel \\
\hline
\end{tabular}

Stasiun klimatologi yang digunakan diambil dari 3 stasiun klimatologi yang dapat mewakili daerah 3 bagian DAS Cisadane, yaitu hulu, tengah dan hilir dengan pembagian seperti pada Tabel 6.

Tabel 6. Stasiun klimatologi dan meteorologi DAS Cisadane

\begin{tabular}{|l|l|l|l|l|l|}
\hline \multirow{2}{*}{ No } & \multirow{2}{*}{$\begin{array}{c}\text { Segmen } \\
\text { DAS }\end{array}$} & \multicolumn{2}{|c|}{$\begin{array}{c}\text { Stasiun } \\
\text { Klimatologi }\end{array}$} & \multicolumn{1}{c|}{$\begin{array}{c}\text { Kab } \\
\text { /Kota }\end{array}$} & \multicolumn{2}{|c|}{ Geografis } \\
\cline { 5 - 6 } 1 & \multirow{2}{*}{ Hulu } & $\begin{array}{l}\text { Kelas III } \\
\text { Citeko }\end{array}$ & $\begin{array}{l}\text { Kabupaten } \\
\text { Bogor }\end{array}$ & $\begin{array}{l}640^{\prime} \\
56^{\prime \prime}\end{array}$ & $\begin{array}{l}106 \\
55^{\prime} \\
16^{\prime \prime}\end{array}$ \\
\hline \multirow{2}{*}{2} & \multirow{2}{*}{ Tengah } & $\begin{array}{l}\text { Kelas } \\
\text { Darmaga } \\
\text { Bogor }\end{array}$ & Kota Bogor & $\begin{array}{l}635^{\prime} \\
40^{\prime \prime}\end{array}$ & $\begin{array}{l}106 \\
43^{\prime} \\
46^{\prime \prime}\end{array}$ \\
\hline \multirow{2}{*}{3} & \multirow{2}{*}{ Hilir } & $\begin{array}{l}\text { Kelas } \\
\text { Pondok II } \\
\text { Betung }\end{array}$ & $\begin{array}{l}\text { Kota } \\
\text { Tangerang } \\
\text { Selatan }\end{array}$ & $\begin{array}{l}69^{\prime \prime} \\
21^{\prime \prime}\end{array}$ & $\begin{array}{l}106 \\
50^{\prime} \\
30^{\prime \prime}\end{array}$ \\
\hline
\end{tabular}

\section{METODOLOGI}

Data dan asumsi yang diperlukan untuk perhitungan metode Mock adalah sebagai berikut:

\section{a. Data Curah Hujan}

Data curah hujan yang digunakan adalah curah hujan 10 harian. Stasiun curah hujan yang dipakai adalah stasiun yang dianggap mewakili kondisi hujan di daerah tersebut.

\section{b. Evapotranspirasi Terbatas}

Evapotranspirasi terbatas adalah evapotranspirasi aktual dengan mempertimbangkan kondisi vegetasi dan permukaan tanah serta frekuensi curah hujan. Untuk menghitung evapotranspirasi terbatas diperlukan data:

- Curah hujan 10 harian (P)

- Jumlah hari hujan (n)

- Jumlah permukaan kering 10 harian (d) dihitung dengan asumsi bahwa tanah dalam suatu hari hanya mampu menahan air $12 \mathrm{~mm}$ dan selalu menguap sebesar $4 \mathrm{~mm}$.

- Exposed surface $(\mathrm{m} \%)$ ditaksir berdasarkan peta tata guna lahan atau dengan asumsi:

$\mathrm{m}=0 \%$ untuk lahan dengan hutan lebat

$\mathrm{m}=0 \%$ pada akhir musim hujan dan bertambah $10 \%$ setiap bulan kering untuk lahan sekunder.

$m=10 \%-40 \%$ untuk lahan yang tererosi.

$m=20 \%-50 \%$ untuk lahan pertanian yang diolah.

Secara matematis evapotranspirasi dirumuskan sebagai berikut: 


$$
\begin{aligned}
& \Delta \mathrm{E}=\operatorname{Epm} \frac{\mathrm{m}}{20}(18-\mathrm{n}) \\
& E_{\text {actual }}=\mathrm{Epm}-\Delta \mathrm{E} \\
& \text { Dengan: } \\
& \Delta \mathrm{E} \quad=\text { Beda antara evapotranspirasi } \\
& \text { potensial dengan } \\
& \text { evapotranspirasi terbatas }(\mathrm{mm}) \\
& E_{\text {actual }}=\text { Evapotranspirasi terbatas }(\mathrm{mm}) \\
& \mathrm{Epm}=\text { Evapotranspirasi potensial }(\mathrm{mm}) \\
& \mathrm{m} \quad=\text { singkapan lahan (Exposed } \\
& \text { surface) } \\
& \mathrm{n} \quad \text { =jumlah hari hujan }
\end{aligned}
$$

\section{c. Faktor Karakteristik Hidrologi}

Faktor Bukaan Lahan:

$$
\begin{aligned}
m= & 0 \% \text { untuk lahan dengan hutan lebat } \\
m= & 10-40 \% \text { untuk lahan tererosi } \\
m= & 30-50 \% \text { untuk lahan pertanian } \\
& \text { yang diolah. }
\end{aligned}
$$

Berdasarkan hasil pengamatan di lapangan untuk seluruh daerah studi yang merupakan daerah lahan pertanian yang diolah dan lahan tererosi, maka dapat diasumsikan untuk faktor $m$ diambil $30 \%$.

\section{d. Luas Daerah Pengaliran}

Semakin besar daerah pengaliran dari suatu aliran kemungkinan akan semakin besar pula ketersediaan debitnya.

\section{e. Water Surplus}

Water Surplus didefinisikan sebagai curah hujan yang telah mengalami evapotranspirasi dan mengisi soil storage (SS). Water Surplus secara langsung berpengaruh pada infiltrasi / perkolasi dan total run-off yang merupakan komponen dari debit. Persamaan Water Surplus (WS) adalah sebagai berikut:

\section{$\mathbf{W S}=\mathbf{( P}-\mathbf{E a})+\mathbf{S S}$}

Water Surplus adalah air permukaan run-off dan infiltrasi. Soil moisture storage (SMS) terdiri dari soil moisture capacity (SMC), zona dari infiltrasi, limpasan permukaan dan soil storage.

Besarnya Soil moisture storage (SMS) untuk masing-masing wilayah tergantung pada jenis tanaman, tutupan lahan (land cover) dan jenis tanah. Dalam Mock, SMS dihitung sebagai berikut:

$$
\text { SMS = ISMS + (P - Ea) }
$$

\section{f. Kapasitas Kelembaban Tanah (SMC)}

Soil Moisture Capacity adalah kapasitas kandungan air pada lapisan tanah permukaan (surface soil) per m2. Besarnya $S M C$ untuk perhitungan ketersediaan air ini diperkirakan berdasarkan kondisi porositas lapisan tanah permukaan dari DPS. Semakin besar porositas tanah akan semakin besar pula SMC yang ada. Dalam perhitungan ini nilai SMC diambil antara 50 $\mathrm{mm}$ sampai dengan $200 \mathrm{~mm}$. Persamaan yang digunakan untuk besarnya kapasitas kelembaban tanah adalah:

$$
\text { SMS }=\text { ISMS }+\mathrm{P}-E_{\text {actual }}
$$

$$
\mathrm{WS}=\mathrm{ISMS}+\mathrm{P}-E_{\text {actual }}-\mathrm{SMS}
$$

Dengan:

$$
\begin{array}{rlr}
E_{\text {actual }}= & \text { evapotranspirasi } & \text { aktual, } \\
& \text { mm/bulan; } & \\
\text { SMS }= & \text { simpanan kelembapan } & \text { tanah, } \\
& \text { mm/bulan; } \\
\text { ISMS }= & \text { kelembaban tanah awal, } \\
& \text { mm/bulan; } \\
\mathrm{P}= & \text { curah hujan bulanan, } \mathrm{mm} / \mathrm{bulan} ; \\
W S \quad= & \text { kelebihan air, mm/bulan; }
\end{array}
$$

Untuk lebih mudah dimengerti proses perhitungan dengan menggunakan Metoda FJ. Mock dapat dilihat pada diagram Gambar 5.

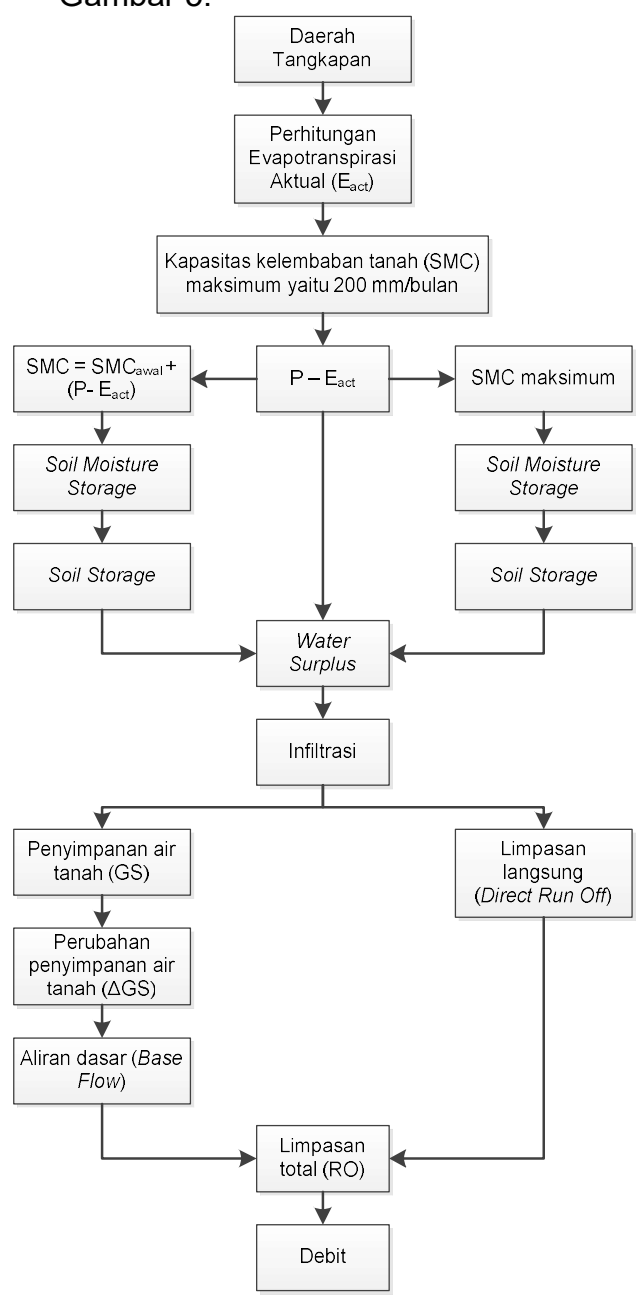

Gambar 5. Diagram metode F.J. Mock. 


\section{HASIL ANALISA}

\subsection{Curah Hujan}

Berdasarkan luas DAS Cisadane yaitu sebesar 1.343,77 $\mathrm{km}^{2}$, maka metode yang sebaiknya digunakan untuk mencari curah hujan rata-rata daerah adalah metode poligon thiessen, tetapi melihat kondisi DAS Cisadane yang memiliki kecenderungan luas DAS yang lebih besar di bagian hulu menyebabkan hasil sebaran hujan rancangan yang didapatkan kurang merata (terlalu besar) karena curah hujan di daerah hulu yang lebih tinggi. Sehingga pada perhitungan ini digunakan metode pendekatan rerata aljabar yang dibagi dalam 3 bagian, yaitu hulu, tengah dan hilir sesuai dengan karakteristik wilayah. Dari 3 bagian tersebut maka dipilih beberapa pos hujan seperti pada Tabel 6 yang dapat mewakili daerah yang ada. Berikut adalah hasil perhitungan ratarata curah hujan DAS Cisadane bagian hulu pada tahun 2006.

Tabel 7. Curah hujan rata-rata DAS Cisadane Hulu tahun 2006

\begin{tabular}{|l|l|l|l|}
\hline \multirow{2}{*}{ Bulan } & \multicolumn{3}{|c|}{ Pos Hujan (mm/bulan) } \\
\cline { 2 - 4 } & Leuwiliang & \multicolumn{1}{|c|}{ Ciomas } & $\begin{array}{c}\text { Rata- } \\
\text { Rata }\end{array}$ \\
\hline Jan & 380 & 389,2 & 384,6 \\
\hline Feb & 131 & 263,4 & 197,2 \\
\hline Mar & 165 & 223,6 & 194,3 \\
\hline Apr & 233 & 216,0 & 224,5 \\
\hline Mei & 198 & 175,1 & 186,55 \\
\hline Jun & 149 & 140,7 & 144,85 \\
\hline Jul & 33 & 36,4 & 34,7 \\
\hline Ags & 69 & 5,0 & 37 \\
\hline Sep & 58 & 57,4 & 57,1 \\
\hline Okt & 219 & 281,2 & 250,1 \\
\hline Nov & 474 & 394,5 & 434,25 \\
\hline Des & 374 & 251,8 & 312,9 \\
\hline
\end{tabular}

Sumber: BMKG dan Perhitungan

\subsection{Klimatologi}

Penggunaan data klimatologi didapatkan dari stasiun meteorologi dan klimatologi yang mewakili daerah DAS Cisadane. Dalam hal ini terdapat 3 stasiun klimatologi atau meteorologi terdekat untuk dapat mewakili DAS Cisadane bagian hulu, tengah dan hilir. Stasiun klimatologi dan meteorologi yang digunakan dapat dilihat pada Tabel 6.

Data klimatologi yang digunakan dalam analisis perhitungan berupa data suhu udara, lamanya penyinaran matahari, kecepatan angin dan kelembaban udara. Tabel 8 dan Tabel 9 menunjukkan hasil rekap data dari tiga stasiun klimatologi berupa hasil rata-rata bulanan selama tahun 2005-2014.
Tabel 8. Data iklim rata - rata bulanan stasiun Meteorologi Citeko

\begin{tabular}{|l|l|l|l|l|}
\hline Bulan & $\mathbf{T}\left({ }^{\circ} \mathbf{C}\right)$ & $\mathbf{n} / \mathbf{N}(\%)$ & $\begin{array}{c}\text { lembab } \\
(\%)\end{array}$ & $\begin{array}{c}\mathbf{u} \\
(\mathbf{k n o t})\end{array}$ \\
\hline Jan & 20,60 & 16,59 & 88,22 & 6,8 \\
\hline Feb & 20,60 & 11,78 & 89,39 & 6,2 \\
\hline Mar & 21,23 & 23,23 & 85,34 & 6,6 \\
\hline Apr & 21,62 & 30,79 & 84,86 & 5,9 \\
\hline Mei & 21,74 & 33,28 & 84,27 & 5,8 \\
\hline Jun & 21,32 & 33,6 & 83,12 & 5,5 \\
\hline Jul & 21,03 & 37,98 & 80,73 & 5,8 \\
\hline Ags & 21,01 & 57,48 & 79,69 & 5,7 \\
\hline Sep & 21,34 & 50,06 & 78,57 & 5,7 \\
\hline Okt & 21,55 & 41,48 & 81,83 & 5,8 \\
\hline Nov & 21,42 & 32,44 & 85,42 & 5,6 \\
\hline Des & 21,33 & 19,54 & 86,59 & 5,8 \\
\hline Sumber
\end{tabular}

Sumber: BMKG Citeko

Tabel 9. Data iklim rata-rata bulanan stasiun Meteorologi Darmaga

\begin{tabular}{|l|l|l|l|l|}
\hline Bulan & $\mathbf{T}\left({ }^{\circ} \mathbf{C}\right)$ & $\begin{array}{c}\text { n/N } \\
(\%)\end{array}$ & $\begin{array}{c}\text { lembab } \\
(\%)\end{array}$ & $\begin{array}{c}\mathbf{u} \\
(\mathbf{k n o t})\end{array}$ \\
\hline Jan & 25,3 & 68,3 & 82,9 & 3,0 \\
\hline Feb & 25,5 & 53,9 & 83 & 4,0 \\
\hline Mar & 25,7 & 59,1 & 80,5 & 3,0 \\
\hline Apr & 25,9 & 71,3 & 86,9 & 2,0 \\
\hline Mei & 26,1 & 77,4 & 86,05 & 3,0 \\
\hline Jun & 25,8 & 75,2 & 80,55 & 3,0 \\
\hline Jul & 25,2 & 80,8 & 80,15 & 4,0 \\
\hline Ags & 25,5 & 79,6 & 74,05 & 4,0 \\
\hline Sep & 26 & 84,3 & 77,65 & 4,0 \\
\hline Okt & 26,2 & 79,4 & 81,1 & 4,0 \\
\hline Nov & 25,8 & 54,8 & 70,3 & 3,0 \\
\hline Des & 25,7 & 54 & 85,25 & 3,0 \\
\hline
\end{tabular}

\subsection{Evapotranspirasi}

Evapotranspirasi merupakan gabungan antara peristiwa evaporasi dan transpirasi. Dalam perhitungan menggunakan evapotranspirasi metode Penman modifikasi dengan data iklim yang lebih lengkap jika dibandingkan dengan metode lain. Untuk menghitung evapotranspirasi DAS Cisadane, dibagi dalam beberapa daerah yang terdiri dari sub DAS seperti terlihat pada Tabel 10.

Tabel 10. Pembagian sub DAS dalam segmen

\begin{tabular}{|c|c|c|c|}
\hline No & Segmen & Sub DAS & $\begin{array}{l}\text { Luas } \\
\left(\mathrm{km}^{2}\right)\end{array}$ \\
\hline 1 & \multirow{8}{*}{ HULU } & Cisadane Hulu & 46,09 \\
\hline 2 & & Cinagara & 41,79 \\
\hline 3 & & Cisalopa & 30,37 \\
\hline 4 & & Citaminag & 56,44 \\
\hline 5 & & Cigombong & 69,20 \\
\hline 6 & & Cimanggis & 56,98 \\
\hline 7 & & Cikalong & 61,93 \\
\hline 8 & & Cigintung & 58,05 \\
\hline
\end{tabular}




\begin{tabular}{|c|c|c|c|}
\hline 9 & & Cigembrong & 184,50 \\
\hline 10 & & Cimande & 48,91 \\
\hline 11 & & Cikereteg & 44,48 \\
\hline 12 & \multirow{3}{*}{ TENGAH } & Cipaku & 35,21 \\
\hline 13 & & Ciapus & 15,32 \\
\hline 14 & & Cihideung & 49,85 \\
\hline No & Segmen & Sub DAS & $\begin{array}{l}\text { Luas } \\
\left(\mathbf{k m}^{2}\right)\end{array}$ \\
\hline 15 & \multirow{6}{*}{ TENGAH } & Cinangneung & 56,84 \\
\hline 16 & & Ciampea & 70,01 \\
\hline 17 & & Ciaruten & 23,91 \\
\hline 18 & & Cianten & 41,79 \\
\hline 19 & & Cikaniki & 117,31 \\
\hline 20 & & Cipinang & 14,92 \\
\hline 21 & \multirow{5}{*}{ HILIR } & Cihowe & 62,35 \\
\hline 22 & & Jelentreng & 10,88 \\
\hline 23 & & Cisauk & 77,67 \\
\hline 24 & & Cicayur & 44,48 \\
\hline 25 & & Cisabik & 25,66 \\
\hline \multicolumn{3}{|c|}{ TOTAL } & $1.343,77$ \\
\hline
\end{tabular}

Sumber: BBWS Ciliwung -Cisadane

Tabel 11. Debit aliran sungai cigembrong

\begin{tabular}{|c|c|c|c|c|c|c|c|c|c|c|c|c|}
\hline \multicolumn{13}{|c|}{ Debit Rata-rata sungai Cigembrong (m3/detik) } \\
\hline Tahun & $\operatorname{Jan}$ & Feb & Mar & Apr & Mei & Juni & Juli & Ags & Sep & Okt & Nov & Des \\
\hline 2005 & 25,71 & 28,42 & 16,97 & 4,57 & 12,25 & 10,54 & 6,96 & 10,93 & \begin{tabular}{|l}
17,77 \\
\end{tabular} & $\begin{array}{l}75,50 \\
7\end{array}$ & \begin{tabular}{l|l}
0 & 11,09 \\
\end{tabular} & 13,39 \\
\hline 2006 & 17,59 & 8,99 & 7,09 & 9,85 & 7,57 & 4,91 & 3,40 & 2,38 & 1,44 & 4,94 & \begin{tabular}{l|l}
4 & 17,33 \\
\end{tabular} & \begin{tabular}{|l|l}
3 & 11,
\end{tabular} \\
\hline 2007 & 16,17 & 19,38 & 11,27 & 13,06 & 5,75 & 3,65 & 3,18 & 2,22 & 1,34 & $\begin{array}{l}4 \quad 6,40 \\
\end{array}$ & \begin{tabular}{l|l}
0 & 15,88
\end{tabular} & \begin{tabular}{l|l}
80,10 \\
\end{tabular} \\
\hline 2008 & 11,36 & 27,84 & 23,23 & 18,91 & 9,52 & 4,96 & 5,04 & 2,94 & 2,08 & \begin{tabular}{l|l}
8,13 \\
\end{tabular} & \begin{tabular}{l|l}
$33,0,09$ \\
\end{tabular} & 0,16 \\
\hline 2009 & 24,39 & 28,98 & 19,43 & 13,08 & 13,50 & 4,78 & 4,12 & 3,71 & 2,69 & 5,71 & \begin{tabular}{l|l}
1 & 9,664
\end{tabular} & 6 \\
\hline 2010 & 31,24 & 28,23 & 13,44 & 7,49 & 9,03 & 13,29 & 6,65 & 5,75 & 6,88 & \begin{tabular}{l|l}
8,76 \\
8
\end{tabular} & \begin{tabular}{l|l|l}
6 & 7,881
\end{tabular} & 10,28 \\
\hline 2011 & 35,31 & 27,42 & 7,48 & 16,50 & 6,86 & 4,56 & 3,97 & 2,78 & 2,01 & $1 \quad 0,91$ & $\begin{array}{ll}1 & 1,02 \\
\end{array}$ & \begin{tabular}{l|l}
2 & 19,09 \\
\end{tabular} \\
\hline 2012 & 15,62 & 41,52 & 15,00 & 17,19 & 4,88 & 4,84 & 4,48 & 2,61 & 2,02 & 1,17 & 7,55 & \begin{tabular}{|l|l|l}
5 & 20,81 \\
\end{tabular} \\
\hline 2013 & 42,81 & 20,02 & 17,57 & 17,44 & 22,21 & 8,33 & 16,24 & 4,33 & 4,48 & 6,06 & 4,43 & 21, \\
\hline 2014 & 62,56 & 36,07 & 15,52 & 19,81 & 11,53 & 8,27 & 12,92 & 12,53 & 6,15 & $\begin{array}{l}5,78 \\
\end{array}$ & \begin{tabular}{l|l|l}
8 & 24,42
\end{tabular} & \begin{tabular}{l|l|l}
2 & 18,99
\end{tabular} \\
\hline Rata-rata & 28,28 & 26,69 & 14,70 & 13,79 & 10,31 & 6,81 & 6,70 & 5,02 & 4,69 & 5,04 & \begin{tabular}{l|l}
4 & 11,53
\end{tabular} & \begin{tabular}{l|l}
3 & 14, \\
\end{tabular} \\
\hline \multicolumn{13}{|c|}{ Sumber: Perhitungan } \\
\hline \multicolumn{13}{|c|}{ Tabel 12. Debit andalan } \\
\hline \multicolumn{13}{|c|}{ Debit Rata-rata sungai Cigembrong (m3/detik) } \\
\hline Tahun & Jan & Feb & Mar & Apr & Mei & Juni & Juli & Ags & Sep & Okt & Nov & Des \\
\hline 2005 & 62,56 & 41,52 & 23,23 & 19,81 & 22,21 & 13,29 & 16,24 & 12,53 & 17,77 & 15,50 & 24,42 & 21,98 \\
\hline 2006 & 42,81 & 36,07 & 19,43 & 18,91 & 13,50 & 10,54 & 12,92 & 10,93 & 6,88 & 6,40 & 17,33 & 20,81 \\
\hline 2007 & 35,31 & 28,98 & 17,57 & 17,44 & 12,25 & 8,33 & 6,96 & 5,75 & 6,15 & 6,06 & 16,09 & 20,10 \\
\hline 2008 & 31,24 & 28,42 & 16,97 & 17,19 & 11,53 & 8,27 & 6,65 & 4,33 & \begin{tabular}{l|l}
4,48 \\
\end{tabular} & 5,71 & 15,88 & 19,09 \\
\hline 2009 & 25,71 & 28,23 & 15,52 & 16,50 & 9,52 & 4,96 & 5,04 & 3,71 & 2,69 & 4,94 & 11,09 & 18,99 \\
\hline 2010 & 24,39 & 27,84 & 15,00 & 13,08 & 9,03 & 4,91 & 4,48 & 2.94 & 2,08 & 3,76 & 9,64 & 13,39 \\
\hline 2011 & 17,59 & 27,42 & 13,44 & 13,06 & 7,57 & 4,84 & 4,12 & 2,78 & 2,02 & 3,13 & 7,81 & 11,27 \\
\hline 2012 & 16,17 & 20,02 & 11,27 & 9,85 & 6,86 & 4,78 & 3,97 & 2,61 & 2,01 & 2,78 & 7,55 & 10,28 \\
\hline 2013 & 15,62 & 19,38 & 7,48 & 7,49 & 5,75 & 4,56 & 3,40 & 2,38 & 1,44 & 1,17 & 4,43 & 6,94 \\
\hline 2014 & 11,36 & 8,99 & 7,09 & 4,57 & 4,88 & 3,65 & 3,18 & 2,22 & 1,34 & 0,91 & 1,02 & 6,12 \\
\hline Rata-rata & 28,28 & 26,69 & 14,70 & 13,79 & 10,31 & 6,81 & 6,70 & 5,02 & 4,69 & 5,04 & 11,53 & 14,90 \\
\hline 280 & 16,17 & 20,02 & 11,27 & 9,85 & 6,86 & 4,78 & 3,97 & 2,61 & 2,01 & 2,78 & 7,55 & 10,28 \\
\hline 290 & 15,62 & 19,38 & 7,48 & 7,49 & 5,75 & 4,56 & 3,40 & 2,38 & 1,44 & 1,17 & 4,43 & 6,94 \\
\hline
\end{tabular}

Sumber: Perhitungan

Metode ini digunakan karena menggunakan data klimatologi yang lebih lengkap dibandingkan dengan metode lain, sehingga hasilnya akan lebih akurat yang dapat dilihat pada Tabel 14 pada lampiran.
Hasil debit aliran sungai Cigembrong selama 10 tahun dijelaskan pada Tabel 11.

\subsection{Debit Andalan}

Debit andalan dihitung pada setiap sungai atau Sub DAS Cisadane dengan keandalan $80 \%$ dan $90 \%$. Dari data debit 10 tahun, data debit diurutkan dari nilai terbesar hingga terkecil sehingga mendapat nilai probabilitas sebesar $80 \%$ dan $90 \%$ dari urutan data. Berikut pada Tabel 12. merupakan contoh pengurutan data untuk debit andalan sungai Cigembrong.

Selanjutnya untuk menentukan debit andalan sungai-sungai di wilayah DAS Sungai Cisadane dengan cara yang sama perhitungan dilakukan dalam menganalisa sungai Cigembrong ditunjukan pada Tabel 12 sampai dengan Tabel 15.

Seluruh sub Das telah dilakukan analisa debit Andalan dengan metoda F.J Mock, Hasil analisa yang ditampilkan pada makalah ini hanya 3 sub DAS, yaitu Cisadane Hulu, Cisalopa dan Cigombong yang ditunjukan pada Tabel 13 .

Tabel 13. Hasil analisa debit andalan dengan F.J. Mock

\begin{tabular}{|c|c|c|c|c|c|c|c|}
\hline \multirow{2}{*}{ Sub DAS } & \multicolumn{7}{|c|}{ Debit (m3/det) } \\
\hline & & Jan & Feb & Mar & Apr & Mei & Jun \\
\hline \multirow{8}{*}{$\begin{array}{c}\text { Cisadane } \\
\mathrm{H}\end{array}$} & Rerata & 7,37 & 6,94 & 3,87 & 3,61 & 2,70 & 1,83 \\
\hline & Q80 & 4,39 & 6,85 & 3,36 & 2,46 & 1,89 & 1,21 \\
\hline & Q90 & 3,90 & 5,00 & 1,87 & 1,87 & 1,71 & 1,20 \\
\hline & & Jul & Aug & Sep & Okt & Nov & Des \\
\hline & Rerata & 1,79 & 1,33 & 1,22 & 1,29 & 2,88 & 4,10 \\
\hline & Q80 & 1,03 & 0,69 & 0,51 & 0,69 & 1,89 & 2,57 \\
\hline & Q90 & 0,99 & 0,65 & 0,50 & 0,29 & 1,11 & 1,74 \\
\hline & & Jan & Feb & Mar & Apr & Mei & Jun \\
\hline \multirow{8}{*}{ Cisalopa } & Rerata & 4,65 & 4,39 & 2,42 & 2,27 & 1,70 & 1,12 \\
\hline & Q80 & 2,66 & 3,29 & 1,86 & 1,62 & 1,13 & 0,79 \\
\hline & Q90 & 2,57 & 3,19 & 1,23 & 1,23 & 0,95 & 0,75 \\
\hline & & Jul & Aug & Sep & Okt & Nov & Des \\
\hline & Rerata & 1,10 & 0,83 & 0,77 & 0,83 & 1,90 & 2,45 \\
\hline & Q80 & 0,65 & 0,43 & 0,33 & 0,46 & 1,24 & 1,69 \\
\hline & Q90 & 0,56 & 0,39 & 0,24 & 0,19 & 0,73 & 1,14 \\
\hline & & Jan & Feb & Mar & Apr & Mei & Jun \\
\hline \multirow{7}{*}{ Cigombong } & Rerata & 10,61 & 10,01 & 5,51 & 5,17 & 3,87 & 2,56 \\
\hline & Q80 & 6,07 & 7,51 & 4,23 & 3,70 & 2,57 & 1,79 \\
\hline & Q90 & 5,86 & 7,27 & 2,81 & 2,81 & 2,16 & 1,71 \\
\hline & & Jul & Aug & Sep & Okt & Nov & Des \\
\hline & Rerata & 2,51 & 1,88 & 1,76 & 1,89 & 4,32 & 5,59 \\
\hline & Q80 & 1,49 & 0,98 & 0,75 & 1,04 & 2,83 & 3,85 \\
\hline & Q90 & 1,28 & 0,89 & 0,54 & 0,44 & 1,66 & 2,60 \\
\hline
\end{tabular}

\section{KESIMPULAN DAN SARAN}

\subsection{Kesimpulan}

Metode F.J. Mock telah diterapkan untuk memperkirakan besarnya debit andalan suatu daerah aliran sungai Cisadane berdasarkan konsep water balance. Air hujan yang jatuh (presipitasi) akan mengalami evapotranspirasi sesuai dengan vegetasi yang menutupi daerah tangkapan hujan. Evapotranspirasi pada Metode Mock adalah evapotranspirasi yang dipengaruhi 
oleh jenis vegetasi, permukaan tanah dan jumlah hari hujan. Analisis data curah yang digunakan pada penelitian ini yaitu data curah hujan harian bersumber dari BMKG Leuwiliang, Ciomas, Dramaga, Cihampea, Neglasari dan Serpong.

Ketersediaan air andalan yang digunakan disesuaikan dengan keberadaan daerah irigasi. Jika terdapat daerah irigasi maka ketersediaan air andalan menggunakan debit andalan $80 \%$, tetapi jika tidak terdapat daerah irigasi, maka ketersediaan air andalan menggunakan debit andalan 90\%. Perhitungan sisa debit atau ketersediaan akhir di setiap sub DAS merupakan pengurangan ketersediaan debit andalan dengan kebutuhan air total.

Hasil perhitungan evapotranspirasi untuk setiap bulan diperoleh debit bulanan tahun 2005 sampai dengan tahun 2014. Dan rekapitulasi debit bulanan menggunakan Metode F.J Mock diperoleh besarnya debit maksimum berfluktuasi untuk wilayah hulu $5,7 \mathrm{~m}^{3} / \mathrm{det}$, wilayah tengah 8,3 $\mathrm{m}^{3} /$ det dan wilayah hilir $8,9 \mathrm{~m}^{3} /$ det.

\subsection{Saran}

Perlu adanya program untuk mempermudah dalam perhitungan keandalan dengan memasukkan data-data hidrologi yang ada. Perlu adanya peninjauan langsung terhadap evapotranspirasi dan luasan lahan tertutup vegetasi atau tanaman supaya dapat diketahui nilai penguapan secara pasti. Perlu adanya pembuatan atau pembangunan stasiun pencatat debit di daerah hilir supaya mendapatkan nilai yang benar-benar nyata di lapangan.

\section{DAFTAR PUSTAKA}

1. Balai Sungai Cidurian Cisadane. 2014. Pemanfaatan Air dan AWLR Daerah Aliran Sungai Cisadane. Tangerang.

2. Balai Besar Wilayah Sungai Ciliwung Cisadane. 2013. Kebutuhan Air Daerah Aliran Sungai Ciliwung Cisadane. Jakarta.
3. Badan Meteorologi Klimatologi dan Geofisika. 2015. Keadaan Meteorologi dan Klimatologi Citeko. Kabupaten Bogor.

4. Badan Meteorologi Klimatologi dan Geofisika. 2015. Keadaan Meteorologi dan Klimatologi Pondok Betung. Tangerang.

5. Badan Pusat Statistik 2015. Tangerang Dalam Angka. Jakarta. Badan Pusat Statistik.

6. Badan Pusat Statistik 2015. Kabupaten Bogor Dalam Angka. Jakarta. Badan Pusat Statistik.

7. Badan Pusat Statistik 2015. Kota Bogor Dalam Angka. Jakarta. Badan Pusat Statistik.

8. Asep,Abdul,Rahman. 2009. SiklusHidrologi. Jakarta

9. Dumairy. 1992. Ekonomika Sumber Daya Air. Yogyakarta:BPFE.

10. Hanafi,Sutanto,dkk. 2012. Analisis Neraca Air di DAS Kupang dan Sengkarang. Fakultas Geografi Universitas Gadjah Mada.

11. Loebis,J.,dkk. 1993. Hidrologi Sungai. Jakarta:Yayasan Badan Penerbit Pekerjaan Umum.

12. Nurroh,S. 2014. Analisis Identifikasi Degradasi Lingkungan. Yogyakarta:Universitas Gadjah Mada.

13. Priyantoro,D.,dkk. 2010. Analisa Kebutuhan dan Ketersediaan Air Pada DAS Sampeyan. Malang:Fakultas Teknik Universitas Brawijaya.

14. Standar Perencanaan Irigasi. 2010. Kriteria Perencanaan Bagian Jaringan Irigasi KP-01.

15. Suharyanto,dkk. 2001. Pengelolaan Sumber Daya Air dalam Otonomi daerah. Yogyakarta:ANDI OFFSET.

16. Triatmodjo,B. 2008. Hidrologi Terapan. Yogyakarta:Beta Offset.

17. Wiyono,A. 2000. Pengembangan Sumber Daya Air. Bandung:Penerbit ITB. 
LAMPIRAN

Tabel 14. Perhitungan Evapotranspirasi

\begin{tabular}{|c|c|c|c|c|c|c|c|c|c|c|c|c|c|}
\hline EVAPOTRANSPIRASI POTENSIAL & & Jan & $\mathrm{Feb}$ & Mar & Apr & May & Jun & Jul & Aug & Sep & Oct & Nov & Dec \\
\hline 1. ea & mbar & 24,9 & 24,9 & 24,9 & 24,9 & 26,4 & 24,9 & 24,9 & 24,9 & 24,9 & 26,4 & 24,9 & 26,4 \\
\hline 2. $w$ & & 0,7 & 0,7 & 0,7 & 0,7 & 0,71 & 0,7 & 0,7 & 0,7 & 0,7 & 0,71 & 0,7 & 0,71 \\
\hline 3. $1-\mathrm{w}$ & & 0,30 & 0,30 & 0,30 & 0,30 & 0,29 & 0,30 & 0,30 & 0,30 & 0,30 & 0,29 & 0,30 & 0,29 \\
\hline 4. ed = ea.kelembaban & mbar & 21,91 & 21,17 & 21,17 & 21,41 & 22,70 & 19,17 & 20,42 & 18,92 & 19,67 & 21,38 & 21,66 & 22,70 \\
\hline 5. ea-ed & mbar & 2,99 & 3,74 & 3,74 & 3,49 & 3,70 & 5,73 & 4,48 & 5,98 & 5,23 & 5,02 & 3,24 & 3,70 \\
\hline 6. $\mathrm{Ra}$ & $\mathrm{mm} / \mathrm{hari}$ & 15,414 & 15,507 & 15,1643 & 14,1217 & 12,9147 & 12,179 & \begin{tabular}{|l|}
12,4147 \\
\end{tabular} & 13,386 & 14,593 & \begin{tabular}{|l|}
15,3783 \\
\end{tabular} & 15,3783 & 15,3497 \\
\hline 7.Rs & $\mathrm{mm} /$ hari & 4,61 & 6,20 & 5,55 & 5,57 & 5,33 & 6,38 & \begin{tabular}{|l|}
6,28 \\
\end{tabular} & 7,42 & 7,70 & \begin{tabular}{|l|}
8,10 \\
\end{tabular} & 5,90 & 5,45 \\
\hline 8. f(ed) & mbar & 0,13 & 0,14 & 0,14 & 0,14 & 0,13 & 0,15 & 0,14 & 0,15 & 0,14 & 0,14 & 0,14 & 0,13 \\
\hline 9. $\mathrm{f}(\mathrm{n} / \mathrm{N})$ & & 0,18 & 0,35 & 0,29 & 0,34 & 0,37 & 0,56 & 0,53 & 0,61 & 0,56 & 0,56 & 0,32 & 0,27 \\
\hline 10. $\mathrm{f}^{\prime}(\mathrm{t})$ & & 14,8 & 14,8 & 14,8 & 14,8 & 15 & 14,8 & 14,8 & 14,8 & 14,8 & 15 & 14,8 & 15 \\
\hline 11. $\mathrm{f}(\mathrm{u})$ & $\mathrm{m} /$ detik & 1,03 & 0,93 & 0,99 & 0,95 & 0,88 & 0,87 & 0,91 & 1,05 & 0,88 & 1,03 & 0,88 & 1,02 \\
\hline 12. $\mathrm{Rn} I$ & & 0,36 & 0,71 & 0,60 & 0,69 & 0,73 & 1,21 & 1,10 & 1,33 & 1,21 & 1,15 & 0,64 & 0,54 \\
\hline 13. Rn & & 3,10 & 3,94 & 3,57 & 3,49 & 3,27 & 3,57 & 3,61 & 4,23 & 4,57 & 4,92 & 3,78 & 3,55 \\
\hline 14.Koefisien bulanan Penman (c) & & 1,04 & 1,05 & 1,06 & 0,90 & 0,90 & 0,90 & 0,90 & 1,00 & 1,10 & 1,10 & 1,10 & 1,10 \\
\hline 15.Evapotranspirasi potensial penman (Eto) & $\mathrm{mm} / \mathrm{hari}$ & 3,22 & 3,99 & 3,83 & 3,09 & 2,94 & 3,59 & 3,37 & 4,85 & 5,04 & 5,49 & 3,85 & 3,97 \\
\hline 16. Evapotranspirasi potensial penman (Eto) & $\mathrm{mm} /$ bulan & 99,71 & 111,62 & 118,59 & 92,61 & 91,15 & 107,67 & 104,58 & 150,20 & 151,15 & 170,19 & 115,49 & 123,18 \\
\hline \multicolumn{14}{|l|}{ EVAPOTRANSPIRASI AKTUAL } \\
\hline $1 . \mathrm{m}$ & $\%$ & 10 & 10 & 10 & 10 & 10 & 10 & 10 & 10 & 10 & 10 & 10 & 10 \\
\hline 2. n, hari hujan & & 26 & 18 & 21 & 21 & 22 & 9 & 6 & 4 & 11 & 16 & 26 & 25 \\
\hline 3. $\mathrm{m} / 20 \times(18-\mathrm{n})$ & & $-4,00$ & 0,00 & $-1,50$ & $-1,50$ & $-2,00$ & 4,50 & 6,00 & 7,00 & 3,50 & 1,00 & $-4,00$ & $-3,50$ \\
\hline 4. $\Delta \mathrm{E}$ & $\mathrm{mm} /$ bulan & $-3,99$ & 0,00 & $-1,78$ & $-1,39$ & $-1,82$ & 4,84 & 6,27 & 10,51 & 5,29 & 1,70 & $-4,62$ & $-4,31$ \\
\hline $5 . \mathrm{E}$ act & $\mathrm{mm} /$ bulan & 103,70 & 111,62 & 120,37 & 94,00 & 92,97 & 102,82 & 98,30 & 139,69 & 145,86 & 168,49 & 120,11 & 127,50 \\
\hline
\end{tabular}

Sumber : Perhitungan 
Tabel 15. Perhitungan Debit Bulanan

\begin{tabular}{|c|c|c|c|c|c|c|c|c|c|c|c|c|c|c|c|}
\hline WATER BALANCE & & & & Jan & $\mathrm{Feb}$ & Mar & Apr & May & Jun & Jul & Aug & Sep & Oct & Nov & Dec \\
\hline 1.P-E act & $\mathrm{mm} / \mathrm{bulan}$ & & & 280,90 & 85,58 & 73,93 & 130,50 & 93,58 & 42,03 & $-63,60$ & $-102,69$ & $-88,16$ & 81,61 & 314,14 & 185,40 \\
\hline 2. SMS & mm/bulan & & & 481 & 286 & 274 & 331 & 294 & 242 & 136 & 34 & (54) & 282 & 514 & 385 \\
\hline 3. Soil Moisture Capacity & $\mathrm{mm} / \mathrm{bulan}$ & $\operatorname{CSM} \rightarrow$ & 200 & 200 & 200 & 200 & 200 & 200 & 200 & 136 & 34 & (54) & 200 & 200 & 200 \\
\hline 4. Soil Storage & $\mathrm{mm} /$ bulan & & & & - & - & - & - & & 64 & 103 & 88 & - & - & \\
\hline 5. WS & $\mathrm{mm} / \mathrm{bulan}$ & & & 280,90 & 85,58 & 73,93 & 130,50 & 93,58 & 42,03 & 0,00 & 0,00 & 0,00 & 81,61 & 314,14 & 185,40 \\
\hline \multicolumn{16}{|c|}{ LIMPASAN \& PENYIMPANAN AIR TANAH } \\
\hline 1. Infiltrasi & $\mathrm{mm} / \mathrm{bulan}$ & & & 84,27 & 25,67 & 22,18 & 39,15 & 28,07 & 12,61 & 0,00 & 0,00 & 0,00 & 24,48 & 94,24 & 55,62 \\
\hline 2. k (Ground Water Resession) & & & & 0,80 & 0,80 & 0,80 & 0,80 & 0,80 & 0,80 & 0,70 & 0,70 & 0,75 & 0,80 & 0,80 & 0,80 \\
\hline 3. $0,5(1+\mathrm{k})$ & $\mathrm{mm} / \mathrm{bulan}$ & & & 0,90 & 0,90 & 0,90 & 0,90 & 0,90 & 0,90 & 0,85 & 0,85 & 0,88 & 0,90 & 0,90 & 0,90 \\
\hline 4. k.GSawal & $\mathrm{mm} / \mathrm{bulan}$ & & & 201,33 & 221,74 & 195,88 & 172,67 & 166,33 & 153,27 & 115,23 & 80,66 & 60,50 & 48,40 & 56,35 & 112,93 \\
\hline 5. GS & $\mathrm{mm} / \mathrm{bulan}$ & Gsom $\rightarrow$ & 251,67 & 277,18 & 244,85 & 215,84 & 207,91 & 191,59 & 164,62 & 115,23 & 80,66 & 60,50 & 70,43 & 141,16 & 162,99 \\
\hline $6 . \Delta G S$ & $\mathrm{~mm} / \mathrm{bulan}$ & & & 25,51 & $-32,33$ & $-29,01$ & $-7,93$ & $-16,32$ & $-26,97$ & $-49,39$ & $-34,57$ & $-20,17$ & 9,94 & 70,73 & 21,83 \\
\hline 7. Aliran dasar & $\mathrm{mm} / \mathrm{bulan}$ & & & 58,76 & 58,00 & 51,19 & 47,08 & 44,39 & 39,58 & 49,39 & 34,57 & 20,17 & 14,55 & 23,51 & 33,79 \\
\hline 8. Limpasan Langsung & mm/bulan & & & 196,63 & 59,90 & 51,75 & 91,35 & 65,50 & 29,42 & 0,00 & 0,00 & 0,00 & 57,13 & 219,89 & 129,78 \\
\hline 9. Limpasan & $\mathrm{mm} / \mathrm{bulan}$ & & & 255,39 & 117,91 & 102,94 & 138,43 & 109,89 & 69,00 & 49,39 & 34,57 & 20,17 & 71,67 & 243,41 & 163,58 \\
\hline 10. Debit & $\mathrm{m}^{3} /$ detik & & & 17,59 & 8,99 & 7,09 & 9,85 & 7,57 & 4,91 & 3,40 & 2,38 & 1,44 & 4,94 & 17,33 & 11,27 \\
\hline
\end{tabular}

